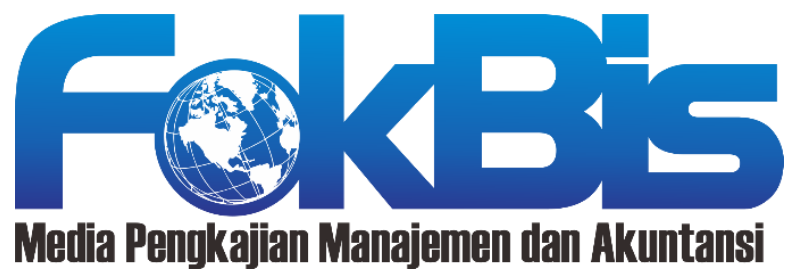

http://journal.stieputrabangsa.ac.id/index.php/fokbis/index

ISSN: 2623-2480/ P-ISSN: 1693-5209

\section{Co-Creation \& Retensi Pelanggan dalam Bangunan Strategi Kemitraan Virtual}

\section{Muhammad Baehaqi}

Sekolah Tinggi Ilmu Ekonomi Putra Bangsa

email: baehaqimuhammad@gmail.com

\section{Article Information}

\section{History of Article:}

Received May $5^{\text {th }} 2020$

Accepted December $11^{\text {th }} 2020$

Published December $31^{\text {st }} 2020$

\section{DOI:}

10.32639/fokusbisnis.v19i2.541

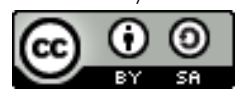

\begin{abstract}
In the turbulance of marketing environment, customer-company relationships are faced with increasingly transparent collaborative mechanisms. Collaborative network of customer-company interfaces was formed as a result of the development of access, media and developing technology. In the customer relationship management model, customer involvement through co-creation becomes the dominant paradigm that shapes customer value. The more customers are involved in determining the expected value, the more customers feel the satisfaction that has implications for company loyalty and ability. Customer retention is a part in it, which can be a triger and mediation for the creation of customer commitment and loyalty.
\end{abstract}

Keywords: Co-Creation, Retensi, Customer Engagement

\title{
PENDAHULUAN
}

Keterlibatan pelanggan -customer engagement- di dalam penciptaan nilai bersama (co-creation) dengan perusahaan telah menjadi topik yang berkembang sejak awal tahun 2000-an (Vargo et al., (2008); Vargo \& Lusch, (2004); dan Prahalad \& Ramaswamy, (2004). Dalam lingkungan bisnis yang dinamis, keterlibatan pelanggan memungkinkan terjadinya peningkatan keunggulan kompetitif melalui promosi penjualan, peningkatan kualitas produk, peningkatan kepuasan pelanggan, serta penurunan biaya dan berbagi resiko (Di Gangi dan Wasko, 2009). Nilai yang diciptakan bersama oleh pelanggan dan perusahaan adalah dasar untuk persaingan di masa depan (Vargo \& Lusch, 2004; Prahalad \& Ramaswamy, 2004), dimana interaksi perusahaan dan pelanggan menjadi elemen kunci dalam proses penciptaan nilai (Banyte \& Dovaliene, 2014). Pelanggan yang terlibat menjadi mitra potensial yang bekerjasama dengan perusahaan, dimana pelanggan ditempatkan sebagai mitra pembuat nilai (Sashi, 2012), sehingga nilai yang dirasakan oleh pelanggan meningkat dengan tingkat keterlibatan mereka dalam penciptaan nilai. Dalam konteks ini, nilai yang diciptakan bukan sekedar 'produk atau layanan' yang dibuat oleh upaya bersama pelanggan dan perusahaan, namun juga melibatkan pengalaman pelanggan dan kepuasan yang lebih besar saat mereka terlibat dalam sebuah transaksi produk atau layanan perusahaan (Prahalad \& Ramaswamy, 2004a). 
Semakin individu berusaha untuk terlibat dalam mencapai tujuan, maka semakin besar nilai yang dirasakan. Karena keterlibatan pelanggan menjadi topik yang relevan, banyak studi cenderung menganalisis masalah dampak keterlibatan pelanggan ke dalam penciptaan nilai pada loyalitas pelanggan. Hasil penelitian menunjukkan bahwa perusahaan mendapatkan manfaat dari keterlibatan pelanggan ke dalam penciptaan nilai, yaitu perusahaan memperoleh keunggulan kompetitif dan pelanggan memiliki kepuasan yang lebih besar yang mengarah ke kesetiaan kepada perusahaan (Banyte \& Dovaliene, 2014).

Teknologi digital telah menghadirkan era percepatan (new wave) yang memungkinkan semua orang terlibat dalam sebuah jejaring untuk tujuan bisnis maupun sosial (Kotler et al., 2010). Dalam skenario digital, interaksi pelanggan--perusahaan bergerak dari model konvensional kearah yang lebih interaktif melalui model virtual. Organisasi bisnis (perusahaan) sebagai mediasi transaksional muncul sebagai coinnovation yang mengusung nilai bersama sebagai desain kemitraan interaktif dalam skenario kolaborasi perusahaan-pelanggan. Tokopedia, Traveloka, Bukalapak, Amazon, E-buy dan sebagainya adalah bukti dari pergeseran model konvensional ke arah virtual. Organisasi terlibat dalam bentuk baru mekanisme kolaboratif dan struktur jaringan yang mampu memberikan keunggulan kompetitif dengan menggabungkan keterampilan terbaik dari kompetensi inti dan sumber daya organisasi, serta melibatkan pengetahuan pelanggan dalam menciptakan proposisi nilai yang lebih menarik dan relevan untuk kebutuhan maupun harapan pelanggan (Romero \& Molina, 2009).

Di sisi lain, pergeseran pelanggan kearah virtual membentuk desain konvergensi kearah komunitas pelanggan yang menunjukkan nilai bisnis yang menjanjikan sebagai "jejaring sosial online" yang mampu menciptakan pengalaman secara keseluruhan. Komunitas pelanggan berpotensi mendukung kustomisasi massal yang memungkinkan pelanggan untuk menjadi co-designer dari produk mereka sendiri, menciptakan inisiatif penjualan dan pemasaran melalui strategi pemasaran viral, dan menciptakan branding di sekitar gaya hidup yang terkait dengan produk mereka (Romero \& Molina, 2009). Eksplorasi keterlibatan pelanggan mengarah pada "komunitisasi" pelanggan dalam arah kedekatan antar membernya satu sama lain yang memiliki kesamaan dalam tujuan (purposes), nilai-nilai (values) dan ketertarikan (interest) diantara mereka sendiri (Seth Godin, 2009). Komunitas yang ideal bagi organisasi untuk diajak kolaborasi adalah komunitas yang memiliki tujuan, nilai, dan ketertarikan yang sesuai dengan karakter perusahaan.

Membangun kemampuan baru untuk bersaing di masa depan menyiratkan desain dan pengembangan lingkungan pengalaman inovatif yang didukung oleh kolaborasi infrastruktur teknologi informasi dan komuniasi (ICT). Melalui media digital dan infrastruktur ICT, pelanggan bergerak menciptakan nilai bersama dengan organisasi (perusahaan) melalui kostumisasi yang digerakkan oleh kolaborasi, konvergensi maupun co-creation (Lee et al., 2012). Ini memungkinkan interaksi antara komunitas pelanggan dan perusahaan, yang kemudian memungkinkan penciptaan nilai bersama dengan desain kemitraan yang saling terhubung.

Tujuan artikel ini adalah untuk mendiskusikan bagaimana co-creation dan customer engagement membentuk model kemitraan melalui mekanisme kolaboratif jaringan pengalaman organisasi-pelanggan. Konstruk yang dibangun tidak saja menampilkan pola hubungan yang mengarah kepada keunggulan kompetitif perusahaan, namun lebih dari itu bagaimana co-creation dan customer engagement mampu membentuk model kemitraan yang mengarah pada retensi dan perikatan hubungan pelangganperusahaan yang menjadi keunggulan kompetitif jangka panjang. Model keterikatan jaringan dikembangkan berdasar pengalaman yang mewakili komunitas pelanggan dan organisasi bisnis yang dibangun berdasar nilai saling keterikatan, sehingga membentuk aliansi bisnis yang potensial sebagai kekuatan dan keunggulan kompetitif masa depan. 


\section{KAJIAN LITERATUR}

\section{Network Collaborative}

Mekanisme bisnis dimulai ketika pelanggan bertemu dengan brand perusahaan untuk melakukan interaksi dan komunikasi yang kemudian terjadi transaksi dan hubungan. Pelanggan datang dengan membawa berjuta kebutuhan dan keinginan, sementara perusahaan menghadirkan beragam produk dan layanan yang ditawarkan. Keterbatasan produk dan layanan perusahaan menjadikan pelanggan tidak terlayani secara baik kebutuhan dan keinginannya, sementara bagi perusahaan, persediaan yang berlimpah tidak terserap dengan baik karena keterbatasan jumlah pelanggan. Inilah yang terjadi dalam konteks bisnis model konvensional. Ruang dan waktu menjadi keterbatasan yang mebelit pelangganperusahaan dalam melakukan transaksi dan hubungan.

Teknologi informasi dan komunikasi muncul sebagai peretas jembatan untuk menghubungkan pelangganperusahaan dalam ruang dan waktu yang lebih signifikan. Penciptaan nilai bersama antara pelangganperusahaan terjadi melalui kolaborasi antar perusahaan dalam upaya membentuk proposisi nilai pelanggan yang lebih baik dan relevan (Romero \& Molina, 2009). Perusahaan terlibat dalam bentuk baru mekanisme kolaboratif dalam struktur jaringan yang mampu memberikan keunggulan kompetitif dengan menggabungkan kompetensi inti dan sumber daya dari dua atau lebih perusahaan. Dalam pengertian ini, jaringan kolaboratif merupakan paradigma yang menjanjikan dengan komunitas pelanggan untuk penekanan pada kompetensi inti, personalisasi dan inovasi. Hal ini memungkinkan pelanggan untuk mengakses produk dan layanan dengan aplikasi, memberi preferensi, memainkan konfigurasinya sendiri, dan oleh karena itu menciptakan nilai dalam upaya kolaboratif (Camarinha-matos \& Afsarmanesh, 2006).

Dalam konteks ini, mekanisme kolaborasi memunculkan collaborative network (CN) sebagai pengembangan yang menjanjikan bagi entitas bisnis dalam menghadapi tantangan yang terus meningkat. Pengurangan hambatan komersial tidak saja memberi akses pelanggan yang lebih luas terhadap barang dan layanan, tetapi juga mengarah pada tuntutan yang lebih tinggi akan kualitas dan keragaman, serta peningkatan secara substansial dalam persaingan antar pemasok (Luis M Camarinha-Matos \& Hamideh Afsarmanesh, 2006). Mekanisme ini diyakini mampu memberi manfaat yang luas bagi setiap partisipasi entitas bisnis yang terlibat. Akuisisi pelanggan dalam dimensi yang lebih besar seperti akses ke pasar baru yang lebih luas, munculnya pengetahuan baru, berbagi risiko dan sumber daya, kolaborasi keterampilan dan kapasitas komplementer yang memungkinkan setiap entitas bisnis untuk fokus pada kompetensi, dan yang tidak kalah penting adalah menjaga survivalitas perusahaan agar tidak tergerus oleh turbulensi arus persaingan. Selain itu, collaborative network juga mendorong terciptanya inovasi yang akan menciptakan nilai baru melalui konvergensi ide dan praktik, kombinasi sumber daya dan teknologi, dan penciptaan sinergi (Camarinha-matos \& Afsarmanesh, 2006).

Gambar 1 menunjukkan CN terbentuk setelah model konvensional dilalui. Kendati cara konvensional untuk mendapatkan keunggulan kompetitif seperti biaya, kualitas, kecepatan respon dan pelayanan masih sangat penting, tetapi untuk dapat memiliki daya saing yang lebih kuat di masa depan perusahaan membutuhkan pengembangan kemampuan baru untuk menciptakan nilai melalui pengalaman. Tuntutan ke arah survivalitas mendorong perusahaan untuk terlibat dalam desain baru saling keterikatan dalam satu bangunan kolaborasi. Keyakinan bahwa kolaborasi akan membawa keadaan yang lebih baik, disitulah nilai baru terbentuk melalui co-creation dalam bingkai organisasi baru dari pola konvensional kearah virtual. Melalui co-creation dalam area virtual, Collaborative Network Organization (CNO) muncul dalam menciptakan proposisi nilai yang baru. 


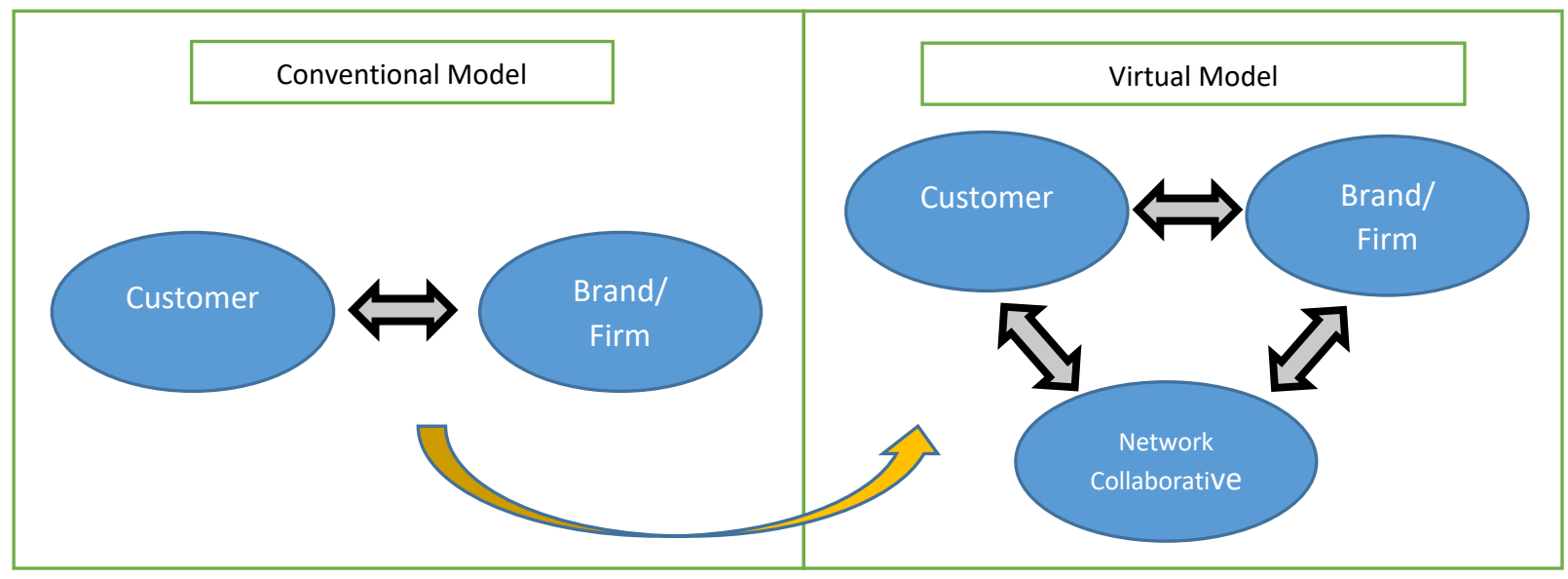

Gambar 1. Model interaksi pelanggan

Peran keterlibatan pelanggan ke dalam penciptaan nilai untuk pengembangan hubungan ditunjukkan dalam pengembangan pola hubungan dari konvensional ke arah virtual. Pada awalnya, keterikatan hubungan terbentuk pada proses transaksi pelanggan-perusahaan secara konvensional. Keterlibatan pelanggan semakin besar dalam model virtual, dimana pelanggan dapat mengakses dan menentukan sendiri nilai yang diharapkan. Sebagian besar penulis menganggap proses tersebut merupakan nilai terbaik untuk penciptaan pelanggan di semua tahap siklus kehidupan perusahaan sebagai solusi dasar untuk mengembangkan hubungan dengan pelanggan. Prahalad \& Ramaswamy, (2004a) setuju dengan pendekatan ini dan menyatakan bahwa pelanggan modern tidak hanya puas dengan perolehan produk dan layanan. Akan tetapi, lebih jauh pelanggan dapat mengakses informasi tentang produk dan layanan, memperoleh informasi transparansi perusahaan, memperoleh ekspektasi yang diinginkan melalui mekanisme keterlibatan pelanggan, serta melibatkan pengalaman individu mereka saat menciptakan nilai bagi pelanggan.

Dalam hal ini, interaksi pelanggan-perusahaan menjadi elemen kunci dalam proses penciptaan nilai. Pelanggan yang terlibat menjadi mitra yang bekerja sama dengan perusahaan dalam proses penciptaan nilai bersama untuk memenuhi kebutuhan pelanggan. Sehingga dalam konteks ini, perusahaan akan menempatkan pelanggan menjadi mitra pembuat nilai (co-creator). Higgins \& Scholer, (2009) menyatakan bahwa semakin individu berusaha untuk mencapai tujuan dan terlibat, semakin besar nilai yang dirasakan. Penegasan yang sama diungkapkan oleh Vargo et al., (2008) bahwa menurutnya, semua penelitian yang dilakukan sejauh ini menegaskan bahwa partisipasi pelanggan dalam proses penciptaan nilai sangat penting untuk pengembangan produk atau layanan inovatif yang akan memuaskan kebutuhan pelanggan. Konsep keterlibatannya didasarkan pada perspektif mengelola layanan dan hubungan dengan pelanggan. Dalam perspektif ini, pemikiran Vargo tentang logika service-dominant mencerminkan pengalaman interaktif dari kreasi pelanggan dalam konteks menciptakan hubungan dengan pemangku kepentingan lainnya (Vargo, 2008). Peran tersebut ditunjukan pada proses kolaboratif dalam model virtual yang menghasilkan CNO pada gambar 1.

Keterlibatan pelanggan sebagai perspektif baru untuk manajemen hubungan pelanggan juga disebutkan oleh Verhoef et al., (2010). Keterlibatan pelanggan dan penciptaan nilai bersama dipandang sebagai bagian dari strategi perusahaan dalam kaitannya dengan pengembangan manajemen hubungan dengan pelanggan. Pandangan yang searah juga ditunjukkan oleh Vivek et al., (2012) melalui pendekatan mereka pada perspektif pemasaran hubungan yang dalam pengembangan hubungan jangka panjang yang berharga dengan pelanggan melalui nilai co-creation. Arah dari konteks hubungan ini adalah penekanan 
yang sama pada nilai yang bisa dihasilkan perusahaan melalui nilai pelanggan, keunggulan produk baru, dan loyalitas sebagai hasil yang menentukan nilai perusahaan yang secara langsung dipengaruhi oleh keterlibatan pelanggan

\section{Experience Network Mechanism}

Strategi penciptaan nilai bersama menggambarkan tindakan yang bertujuan untuk mengkonfigurasikan sistem penciptaan nilai sebagai sekumpulan orang, organisasi, dan teknologi yang bertindak sebagai simbiosis ekosistem bisnis di mana pelanggan-perusahaan berinteraksi secara dinamis dan timbal balik untuk membentuk komitmen bersama dalam menghasilkan nilai penawaran barang, jasa dan pengalaman (Romero \& Molina, 2009). Dalam konteks penciptaan nilai, strategi dan model bisnis terus-menerus mengalami perkembangan dari waktu ke waktu dalam proses menemukan sumber-sumber nilai, peluang dan cara yang baru untuk melakukan co-creation antara pelanggan dan stake holder dalam jangka panjang. Oleh karena itu, merumuskan strategi akan menjadi proses pencarian yang berkesinambungan dalam memberi pembelajaran aktif dan adaptasi yang fleksibel dalam ekosistem bisnis yang dinamis. Hal ini ditujukan agar mampu mengakses kompetensi baru, mengalokasikan sumber daya secara cepat dan memanfaatkan kapabilitas dan kapasitas perusahaan untuk bersaing berdasarkan pengalaman.

Dalam jaringan virtual, nilai co-creation terbentuk oleh aliansi-aliansi bisnis (perusahaan) dan sekumpulan pelanggan sebagai co-creator (gambar 2) melalui kesesuaian tujuan, nilai-nilai dan ketertarikan. Saling kesesuaian tersebut dengan sendirinya akan mengeliminasi aliansi bisnis dan pelanggan yang tidak dapat dijadikan sebagai target co-creator, dan membentuk saling keterikatan antara perusahaan-pelanggan yang merasakan saling kesesuaian dalam satu jaringan pengalaman. "Komunitisasi" terbentuk dengan munculnya komunitas pelanggan virtual (VCC) searah kedekatan antar membernya satu sama lain yang memiliki kesamaan dalam hal tujuan (purposes), nilai-nilai (values) dan ketertarikan (interest) diantara mereka sendiri (Seth Godin, 2009). VCC menjadi forum yang sangat berharga di mana produk dan layanan pelanggan dapat didiskusikan, dianalisis, dikritik, dan berpotensi ditingkatkan. Lebih jauh lagi, VCC berpotensi muncul sebagai laboratorium bisnis yang nyata di mana banyak pengguna (pelanggan) dari produk yang sama atau berbeda dapat bersatu untuk membahas kualitas dan tingkat kepuasan produk mereka saat ini, atau berkomentar tentang ide-ide pembaharuan, di luar dialog dan negosiasi komersial. Interaksi sosial di antara pelanggan dalam komunitas virtual semacam ini mewakili alur hubungan dan informasi yang berpotensi dalam mengembangkan wawasan yang luas, dan berpotensi besar untuk mendorong hubungan antar perusahaan dengan pelanggan mereka. 


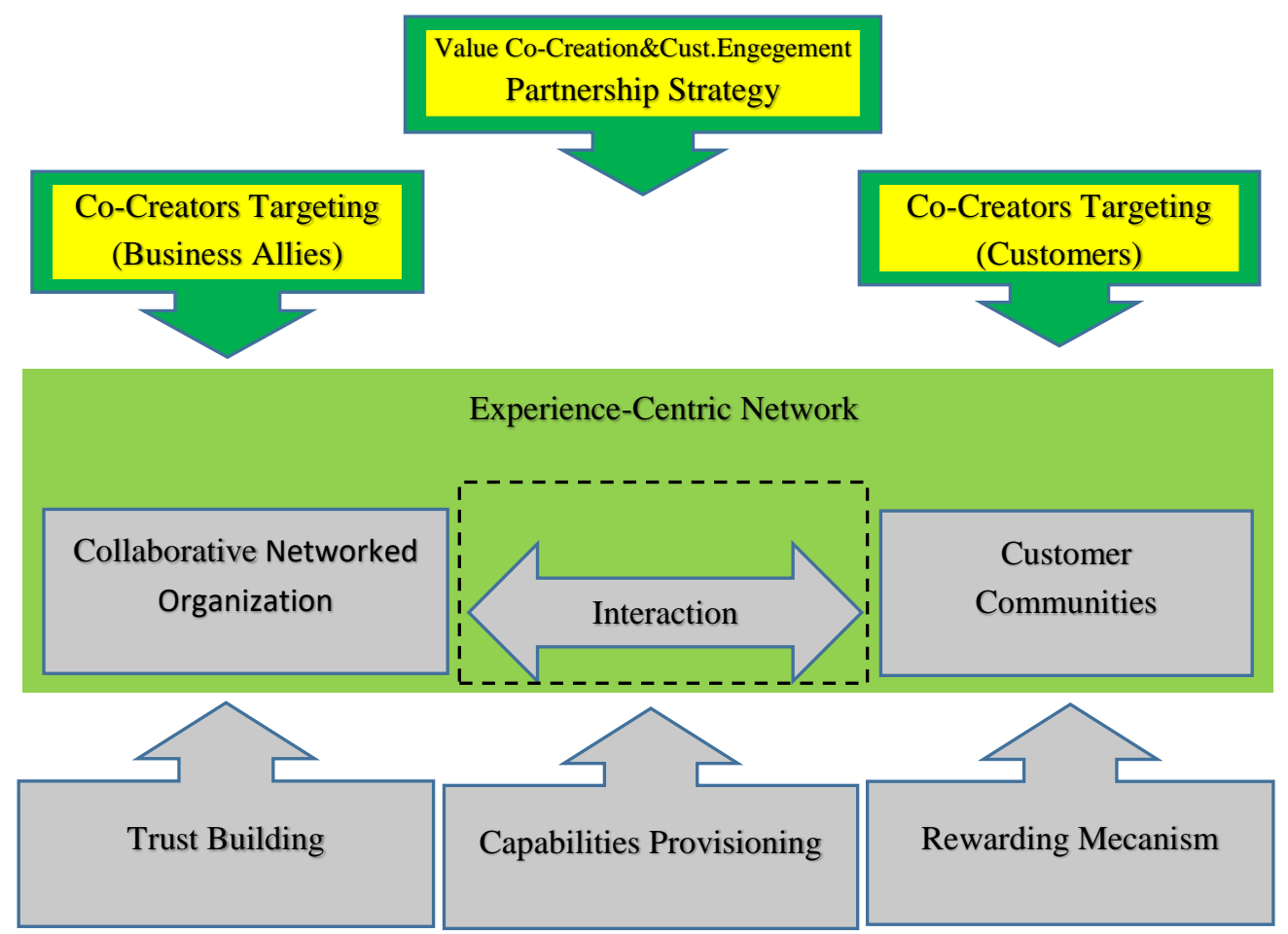

Gambar 2. The framework of experience-centric network reference

Sumber: Romero \& Molina 2011 (modified)

Dalam paradigma relationship, pemikiran Prahalad (2004) tentang co-creation menunjukan relevansi pola komunikasi perusahaan dengan pelanggan dengan penciptaan nilai bersama oleh perusahaan dan pelanggan (Prahalad \& Ramaswamy, 2004a). Co-creation menjadi bangunan konseptual pendekatan dalam inovasi. Melalui inovasi, penciptaan produk dan pengalaman dapat dibentuk melalui kolaborasi perusahaan, pelanggan, pemasok, yang saling terhubung dalam sebuah jaringan inovasi. Product experience, yang dibangun diatas informasi dan hubungan customer experience, yang merupakan akumulasi dari pengalaman individual pelanggan dalam menciptakan nilai utama produk tersebut. Melalui intensitas interaksi yang berkualitas, pelanggan dapat menciptakan pengalaman unik dengan perusahaan, yang kemudian menjadi kunci untuk membuka sumber baru keunggulan kompetitif (Prahalad \& Ramaswamy, 2004a).

CNO dan customer communities yang terseleksi sebagai co-creator dibangun diatas komponen utama yaitu trust building dan rewarding mechanism. Kepercayaan adalah perekat antara pelanggan dan perusahaan untuk menghasilkan value co-creation. Kepercayaan adalah media dimana pelanggan dan perusahaan berdialog dan menjadi landasan utama agar pelanggan dan perusahaan tetap ada. Dengan demikian, kepercayaan mewakili proses bilateral yang membutuhkan komitmen bersama antara pelanggan dan perusahaan untuk saling menciptakan kredibilitas, sehingga menghasilkan interaksi yang kondusif dalam mekanisme jaringan pengalaman (Romero \& Molina, 2009).

Dalam paradigma co-creation, bangunan kepercayaan dapat didukung melalui blok bangunan DART (Prahalad \& Ramaswamy, 2004b); Dialog, Akses, Pengkajian risiko, dan Transparansi. Dialog antara pelanggan dan perusahaan tidak saja melibatkan pengalaman dan kompetensi semata, namun yang lebih krusial adalah pada saat pelanggan dan perusahaan harus berbagi resiko untuk menemukan bangunan 
kepercayaan. Oleh karena itu, dalam proses penciptaan nilai, jelas bahwa melibatkan pelanggan secara langsung dalam penciptaan nilai melibatkan risiko bagi pelanggan dan perusahaan. Dialog akan menjadi elemen yang mendorong tidak hanya berbagi pengetahuan, namun lebih penting lagi, berbagi pemahaman antara kekhawatiran perusahaan dan pelanggan. Dialog juga memberi akses kepada pelanggan untuk berkontribusi di dalam pemikiran, memberikan akses pengetahuan, alat dan mekanisme untuk menciptakan pengalamannya sendiri.

Selain itu, karena risiko yang terlibat untuk kedua belah pihak, penilaian risiko mengasumsikan bahwa jika konsumen menjadi co-creator nilai, mereka akan menuntut lebih banyak informasi tentang potensi risiko yang terkait dengan pengembangan produk, tetapi mereka juga harus menanggung lebih banyak tanggung jawab untuk menangani risiko tersebut. Dengan demikian, transparansi informasi dalam proses interaksi akan diperlukan bagi pelanggan untuk berpartisipasi secara efektif dalam mode kreasi bersama, dan untuk membangun kepercayaan antara perusahaan dan konsumen.

Reward mechanism juga menjadi penting untuk memberi apresiasi kepada pelanggan atas jasa dan kepercayaan yang telah diberikan. Dari sudut pandang perusahaan, reward dapat bermakna upaya diplomatis untuk menarik titik keberpihakan pelanggan kepada perusahaan. Sementara dari sudut pelanggan, reward dapat berarti nilai yang mendasari motivasi pelanggan untuk terlibat dalam sebuah kolaborasi bisnis. Dengan demikian, reward merupakan sebuah konsekuensi hak bagi pelanggan, dan konsekuensi kewajiban bagi perusahaan. Reward mechanism merupakan media dialog yang transparan antara pelanggan dan perusahaan. Reward dapat berbentuk contoh produk, cashback, bonus, programprogram promosi lain yang tugas intinya adalah untuk memberi penghargaan dan apresiasi pada pelanggan.

\section{Retensi Pelanggan Sebagai Moderating Strategi}

Sudah tidak diragukan lagi bahwa co-creation dalam jaringan kolaboratif telah membawa arus besar perilaku pelanggan di era teknologi. Namun demikian, sejauh apa perusahaan mampu menggerakkan pelanggan sebagai aset potensial yang terus dimiliki, akan menjadi problematika yang harus dicarikan solusi. Secara teoritis diakui bahwa keterlibatan pelanggan yang besar akan menciptakan kepuasan dan berpotensi menciptakan kesetiaan bagi perusahaan (Banyte \& Dovaliene, 2014). Ini adalah dasar bagi munculnya antiseden kesetiaan yang pada prinsipnya adalah dasar bagi kemampulabaan perusahaan. Karena semakin perusahaan memiliki pelanggan yang setia, maka semakin tinggi potensi kemampulabaan yang mereka miliki.

Dari sudut pandang pelanggan, keterlibatan pelanggan dalam jaringan virtual dapat ditelusuri dari arah motivasi pelanggan (Füller et al., 2009). Co-creation pelanggan dapat dibangun melalui tiga komponen utama, yaitu konten, proses dan komuniti. Konten menjawab pertanyaan yang diinginkan oleh pelanggan tentang apa yang dapat mereka berikan ketika mereka terlibat. Sementara proses lebih mengedepankan bagaimana mereka terlibat. Apa yang mereka dapatkan ketika pelanggan berpartisipasi, apakah intensitas pergaulan, insentif, menjawab keingintahuan, atau yang lain. Sedangkan komuniti adalah partner area dimana pelanggan dapat mengembangkan kepada dan dengan siapa mereka berinteraksi, melakukan komunikasi sesama pelanggan, atau pelanggan dapat membangun kemitraan dengan orang lain yang dianggap mewakili kepentingannya.

Studi Füller et al., (2009) menemukan bahwa pelangan memiliki motivasi intrinsik dan motivasi ekstrinsik yang kemudian membedakan pelanggan ke dalam empat kategori yaitu; curiusity, need, intrinsic, reward. Motivasi intrinsik menjadi kondisi ideal karena mewakili motivasi pelanggan yang didukung oleh kemampuan inovasi dan kemampuan eksplorasi yang tinggi. Dalam tingkat ini, pelanggan lebih membutuhkan aktualisasi diri, penghargaan, ucapan terima kasih dan pengakuan. Namun ditingkat yang berbeda, motivasi ekstrinsik juga menjadi peluang, karena pelanggan yang memiliki inovasi tinggi dan 
tingkat eksporasi yang rendah, lebih termotivasi oleh reward. Pelanggan dalam kategori ini banyak dipengaruhi oleh harapan yang bersifat finansial, juga karena efek ketidakpuasan pada pemasok lain.

Retensi pelanggan menjadi suatu yang perlu dipertimbangkan sebagai bagian strategi yang efektif bagi perusahaan. Banyak studi mengklaim bahwa retensi pelanggan juga merupakan anteseden yang kuat untuk kesetiaan pelanggan, disamping dapat memediasi antara kepuasan pelanggan terhadap kesetiaan. Dengan fungsi yang demikian, maka dapat dimungkinkan peran retensi sebagai switcing barrier agar pelanggan tidak lari kepada pesaing. Dalam banyak kasus ditemukan bahwa pelanggan memiliki kesetiaan terhadap merek, namun mereka tidak memiliki kesetiaan pada toko atau perusahaan pemasok (CossíoSilva et al., 2016). Pelanggan mencoba mendapatkan produk atau jasa yang mereka kehendaki, dengan mencari nilai tambah yang berbeda ketika mereka menggunakan outlet yang lebih menguntungkan. Persoalannya bukan pada apa yang dikehendaki pelanggan, karena mereka sudah menentukan merek yang mereka pilih, namun permasalahannya ada pada preferensi pemasok yang dikehendaki.

Dalam area kolaborasi jaringan, dimana komuniti dan akses yang sangat transparan, mengembangkan retensi pelanggan sebagai switcing barrier dapat menjadi jawaban bagi perusahaaan untuk membuat keputusan-keputusan strategis. Dengan mengenali motivasi dan kategori pelanggan, perusahaan dapat menentukan sisi potensi yang mampu dipersiapkan sesuai kemampuan sumberdaya perusahaan yang dimiliki. Penting dipertimbangkan adalah bangunan komitmen pelanggan-perusahaan, karena dalam mekanisme kolaboratif yang transparan, komitmen dapat menjadi sisi yang manipulatif, karena banyaknya preferensi dan ketersedaiaan akses dan media. Secara teoritis, retensi pelanggan ditentukan oleh tiga hal yaitu kepuasan pelanggan secara menyeluruh, komitmen afektif dan komitmen kalkulatif (Ndubisi et al., 2010). Menentukan titik tekan pada bangunan komitmen pelanggan, menjadi penting dengan melakukan evaluasi tentang sikap dan minat yang mempengaruhi perilaku pelanggan. Bangunan tersebut secara implisit tergambar dalam gambar 2 dimana mekanisme hubungan dibentuk dan menghasilkan jaringan pengalaman pelanggan. Komitmen sebagai arti membangun hubungan jangka panjang, atau dengan makna pengorbanan untuk menjalin hubungan (Verhoef, 2003), menjadi titik yang harus ditekankan, karena dalam mekanisme kolaboratif ini ketegasan komitmen pelanggan akan menjadi titik keunggulan perusahaan. Dalam konteks menciptakan switcing barrier, komitmen kalkulatif dapat menjadi celah yang dapat dimaksimalkan, karena dalam area ini pelanggan dianggap memiliki motivasi yang relasional, rasional dan matematis. Sehingga dengan menciptakan sistem yang lebih bermotif finansial, menciptakan komitmen kalkulatif dapat menjadi triger bagi switching barrier retensi pelanggan.

\section{SIMPULAN}

Penciptaan nilai telah mengubah gagasan tradisional tentang value creation, di mana pelanggan dilihat sebagai "obyek pasif yang menghabiskan nilai perusahaan", sementara dalam paradigma hubungan, value co-creation memandang pelanggan sebagai "subyek aktif dalam menciptakan kembali nilai dengan perusahaan". Dengan demikian, semua perubahan ini menetapkan tahapan peran yang semakin luas bagi pelanggan, dalam lingkungan pengalaman yang baru, pelanggan tidak lagi menjadi penerima produk yang pasif. Sebagai gantinya, pelanggan kini menjadi mitra aktif yang menciptakan nilai bersama dengan perusahaan.

Customer engagement dan co-creation sebagai bentuk konsep manajemen hubungan dengan pelanggan telah berkembang menjadi konsep pemasaran yang sangat strategis yang memberi kontribusi pada keunggulan kompetitif bagi perusahaan, dan memberi nilai kepuasan bagi pelanggan. Melibatkan pelanggan dalam penciptaan nilai bersama berdampak pada meningkatnya penetrasi pasar, meningkatnya jalinan hubungan dengan pelanggan, potensi profitabilitas yang meningkat, dan munculnya kompetensi baru sebagai hasil kolaborasi antar muka jaringan.

Retensi pelanggan sebagai mediasi pembentukan kesetiaan pelanggan dapat memainkan peran yang dominan mengingat dalam area jaringan kolaborasi pelanggan yang sangat luas, kesetiaan dan komitmen 
menjadi sangat manipulatif dan transparan. Sehingga membangkitkan komitmen pelanggan melalui model retensi yang kalkulatif dapat menjadi pertimbangan yang perlu dipertimbangkan untuk mempertemukan nilai pelanggan dan nilai perusahaan.

\section{REFERENSI}

Banyte, J., \& Dovaliene, A. (2014). Relations between Customer Engagement into Value Creation and Customer Loyalty. Procedia - Social and Behavioral Sciences, 156(April), 484-489. https://doi.org/10.1016/j.sbspro.2014.11.226

Camarinha-matos, L. M., \& Afsarmanesh, H. (2006). Collaborative networks: Value creation in a knowledge society. IFIP International Federation for Information Processing, 207(June 2014), 2640. https://doi.org/10.1007/0-387-34403-9_4

Cossío-Silva, F. J., Revilla-Camacho, M. Á., Vega-Vázquez, M., \& Palacios-Florencio, B. (2016). Value cocreation and customer loyalty. Journal of Business Research, 69(5), 1621-1625. https://doi.org/10.1016/j.jbusres.2015.10.028

Füller, J., Mühlbacher, H., Matzler, K., \& Jawecki, G. (2009). Consumer empowerment through internetbased co-creation. Journal of Management Information Systems, 26(3), 71-102. https://doi.org/10.2753/MIS0742-1222260303

Higgins, E. T., \& Scholer, A. A. (2009). Engaging the consumer: The science and art of the value creation process. Journal of Consumer Psychology, 19(2), 100-114. https://doi.org/10.1016/j.jcps.2009.02.002

Kotler, P., Kartajaya, H., \& Setiawan, I. (2010). Marketing 3.0: From products to customers to the human spirit. John Wiley \& Sons.

Lee, S. M., Olson, D. L., \& Trimi, S. (2012). Co-innovation: Convergenomics, collaboration, and co-creation for organizational values. Management Decision, 50(5), 817-831. https://doi.org/10.1108/00251741211227528

Ndubisi, N. O., Ahmad, R., Buttle, F., Ang, L., Buttle, F., Bijmolt, T. H. A., Leeflang, P. S. H., Block, F., Eisenbeiss, M., Hardie, B. G. S., Lemmens, A., Saffert, P., Ahmad, R., Buttle, F., Nataraj, S., Flint, D. J., Blocker, C. P., Boutin, P. J., Gustafsson, A., ... Krafft, M. (2010). Customer retention management: a reflection of theory and practice. Journal of Service Research, 13(3), 149-161. https://doi.org/10.1108/02634500210428003

Prahalad, C. K., \& Ramaswamy, V. (2004a). Co-creating unique value with customers. Strategy \& Leadership, 32(3), 4-9. https://doi.org/10.1108/10878570410699249

Prahalad, C. K., \& Ramaswamy, V. (2004b). Co-creation experiences: The next practice in value creation. Journal of Interactive Marketing, 18(3), 5-14. https://doi.org/10.1002/dir.20015

Romero, D., \& Molina, A. (2009). Value co-creation and co-innovation: Linking networked organisations and customer communities. IFIP Advances in Information and Communication Technology, 307, 401-412. https://doi.org/10.1007/978-3-642-04568-4_42

Sashi, C. M. (2012). Customer engagement, buyer-seller relationships, and social media. Management Decision, 50(2), 253-272. https://doi.org/10.1108/00251741211203551

Seth Godin, (2009). Confirmation Is Beyond Permission Kompas.com, 30/09/2009

Vargo, S. L. (2008). Customer integration and value creation: Paradigmatic traps and perspectives. Journal of Service Research, 11(2), 211-215. https://doi.org/10.1177/1094670508324260 
Vargo, S. L., \& Lusch, R. F. (2004). Evolving to a New Dominant Logic for Marketing. Journal of Marketing, 68(1), 1-17. https://doi.org/10.1509/jmkg.68.1.1.24036

Vargo, S. L., Maglio, P. P., \& Akaka, M. A. (2008). On value and value co-creation: A service systems and service logic perspective. European Management Journal, 26(3), 145-152. https://doi.org/10.1016/j.emj.2008.04.003

Verhoef, P. C. (2003). Understanding the Effect of Efforts on Customer Retention and. Journal of Marketing, 67(October), 30-45. https://doi.org/10.1016/j.intmar.2011.02.002

Verhoef, P. C., Reinartz, W. J., \& Krafft, M. (2010). Customer engagement as a new perspective in customer management. Journal of Service Research, 13(3), 247-252. https://doi.org/10.1177/1094670510375461

Vivek, S. D., Beatty, S. E., \& Morgan, R. M. (2012). Customer engagement: Exploring customer relationships beyond purchase. Journal of Marketing Theory and Practice, 20(2), 122-146. https://doi.org/10.2753/MTP1069-6679200201 